\title{
Obezitenin Tedavisinde Geçmiş ve Güncel Bariatrik Cerrahi Uygulamaları
}

\author{
Şeyda GÜNGÖR ${ }^{1} \&$ \\ ${ }^{1}$ Beslenme ve Diyetetik Bölümü, Sağlı Bilimleri Fakültesi, Muş Alparslan Üniversitesi, Muş, Türkiye \\ 凹: s.gungor@alparslan.edu.tr (iD) 0000-0003-0333-8966
}

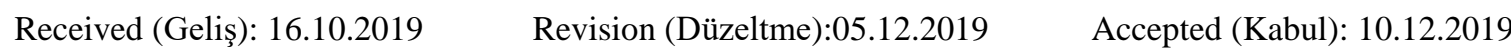

\begin{abstract}
ÖZ
Obezite; çağımızın görülme sıklığı hızla artmakta olan kronik ve kompleks bir hastalığıdır. Obezitenin kanser, metabolik sendrom, tip 2 diyabet gibi bazı hastalıkların yanında kardiyovasküler, renal ve muskuloskeletal sistem bozukluklarının, psikolojik rahatsızlıkların ve diğer birçok işlevsel bozukluğun artışında etkisinin olduğu günümüz literatürünce kabul edilmiştir. Obezitenin tedavisinde düzenli fiziksel aktivite eşliğinde sağlıklı diyet uygulamalarının veya medikal tedavilerin sonuç vermediği durumlarda; donanımlı merkezlerde deneyimli ekipler tarafından bariatrik cerrahi uygulamaları gerçekleștirilmektedir. Sürecin başarılı geçmesi hastaya en uygun bariatrik cerrahi uygulamasına karar verilmesi ve süreç boyunca sürekli beslenme ve metabolik takip ile mümkündür. Her bir uygulamanın ise avantajları ve dezavantajları mevcuttur. Bu derlemede bariatrik cerrahinin eski ve yeni uygulamaları hakkındaki genel bilgiler bir araya getirilmiş̧ir.
\end{abstract}

Anahtar Kelimeler: Bariatrik cerrahi, Morbid obezite, Tedavi Yöntemleri

\section{Past and Current Methods of Bariatric Surgery in the Treatment of Obesity}

\begin{abstract}
Obesity is a chronic and complex disease which is increasing rapidly in recent years. It has been accepted in the current literature that obesity has an effect on the increase of cardiovascular, renal, musculoskeletal system and psychological disorders and many other functional disorders besides some diseases such as cancer, metabolic syndrome, type 2 diabetes. In cases of regular physical activity with healthy diets or pharmacological treatment are not effective in the treatment of obesity, bariatric surgery is performed by experienced teams in well-equipped centers. The success of the process is possible by deciding the most appropriate bariatric surgery for the patient and the nutritional and metabolic monitoring throughout the process. Each application has advantages and disadvantages. In this review, general information about past and current methods of bariatric surgery were collected.
\end{abstract}

Keywords: Bariatric surgery, Morbid obesity, Treatment methods

\section{GíRiș}

Obezite çăgımızın prevelansı gittikçe artmakta olan kronik ve oldukça kompleks bir hastalığıdır [1]. Zamanla birçok komorbiditenin eşlik ettiği obezite tedavisinde fiziksel aktivite, diyet ve medikal tedavinin sonuç vermediği durumlarda bariatrik cerrahi tedavisi başarılı sonuçlar verebilmektedir [2]. İlk ortaya çıktığı günden bu güne kadar kullanılan, değişen veya geliştirilen tüm bariatrik cerrahi uygulamaları kendi içerisinde avantaj ve dezavantajlar barındırmaktadır.

\section{Obezite Tanımı Ve Tanı Kriterleri}

Obezite; vücutta anormal ve aşırı yağ birikimi olarak tanımlanır ve temelde kalori alımı ile yakımı arasındaki dengesizlikten kaynaklanır [1]. Yetişkinlerde obeziteyi sınıflandırabilmek ve vücut metrekaresi başına düşen ağıllığı ifade etmek için Beden Kitle İndeksi (BKI/ BMI- Body Mass Index) kullanılmaktadır. $\mathrm{Bu}$ değer kilogram cinsinden vücut ağırlığının, metre cinsinden boy uzunluğunun karesine bölünmesiyle elde edilir [2]. Dünya Sağllk Örgütü (DSÖ) verilerine göre göre obezite sınıflandırması Tablo 1'de verilmiştir.

Tablo 1. BKİ'ye Göre Obezite Sinıflandırması [2].

\begin{tabular}{ll}
\hline Sinıflandırma & BKİ ( kg/m² $)$ \\
\hline Şiddetli Zayıf & $<16.00$ \\
Orta Zayıf & $16.00-16.99$ \\
Hafif Zayıf & $17.00-18.49$ \\
\hline \multicolumn{1}{c}{ Zayıf (Underweight) } & $<18.50$ \\
\hline Normal (Normal Range) & $18.50-24.99$ \\
\hline Kilolu (Overweight) & $\geq 25.00$ \\
Pre-Obez $\quad 25.00-29.99$ \\
\hline \multicolumn{1}{c}{ Obez (Obese) } & $\geq 30.00$ \\
\hline 1. Sinıf Obez & $30.00-34.99$ \\
2. Sinıf Obez & $35.00-39.99$ \\
3. Sinıf Obez (Morbid) & $\geq 40.00$ \\
\hline
\end{tabular}

BKİ yaş ve cinsiyetten bağımsız olduğu ve vücut yağ dağılımı hakkında bilgi vermediği için obezite tanısı koymada ve obezitenin tipini belirlemede; 
bel çevresi, kalça çevresi, bel/kalça oranı, deri kıvrım kalınlıkları, üst orta kol çevresi gibi antropometrik ölçümlere ihtiyaç duyulabilmektedir [3-5]. Sağlıklı yetișkin bir erkeğin vücut yă yüzdesinin \%8-15, kadının \%15-22 aralığında olması beklenir [4]. Bel çevresinin kadınlarda 80 cm'nin, erkeklerde $94 \mathrm{~cm}$ 'nin üzerinde olması risk durumu; kadınlarda $88 \mathrm{~cm}$ 'nin, erkeklerde 102 $\mathrm{cm}$ 'nin üzerinde olması yüksek risk durumu olarak değerlendirilir [6].

DSÖ; 2016 yılında dünya genelinde 18 yaş üstü bireylerin \%39'unun fazla kilolu; erkeklerin \%11'inin, kadınların ise \%15'inin obez olduğunu bildirmiştir. Bu verilere göre 2016 y1lında dünya çapında 2 milyardan fazla yetişkin fazla kilolu, yarım milyardan fazla yetişkin obez olduğu bilinmektedir [8]. Türkiye İstatistik Kurumu (TÜIK) 2017 verilerine göre ise; 2016 yılinda Türkiye'de 15 yaş ve üzeri obez bireylerin oranı $\% 19.6$ 'dır [7].

Obezite nedenleri çevresel ve genetik faktörler olarak ikiye ayrılabilir. Sosyoekonomiksosyokültürel düzey düşüklüğü, aile yaşantısı, cinsiyet, yaş, sigara kullanımı, endokrin bozukluklar, ilaçlar ve en önemlisi hareketsiz yaşamın benimsenmesi ve sağlıksız beslenme obezitenin başlıca çevresel sebepleri arasında gösterilebilir [5, 9]. Bunun yanı sıra kalıtımın da obezite üzerinde \%30-70 aralığında bir etkisinin olduğu tahmin edilmektedir $[4,10]$. Nitekim evlat edinilen çocuklar üzerinde yapılan bir çalışmada [11] çocukların vücut kompozisyonlarının biyolojik anne babalarıyla daha benzer olduğu belirtilmiştir. Fakat gen defektleri ve kalitımın bu olumsuz etkisinden, düzenli fiziksel aktivite ve sağlıklı beslenme yoluyla kaçınmak mümkündür [12].

Obezitenin birçok kardiyovasküler rahatsızlığı, kas iskelet sistemi rahatsızlıklarını, renal bozuklukları, tip 2 diyabet, metabolik sendrom gibi hastalıkları ve psikososyal durum bozukluklarını beraberinde getirme riskinin yüksek olduğu bilinmektedir [1317]

\section{Obezitenin Tedavisi}

Obezitenin tedavisi diyet-fiziksel aktivite, medikal tedavi ve cerrahi tedavi olmak üzere birkaç aşamaya ayrılabilir. Fiziksel aktivite eşliğinde diyet tedavisinin veya medikal tedavinin sonuç vermediği obezite durumlarında bariatrik cerrahiye başvurulmaktadır [1, 5, 17-20].

Morbid obezite cerrahisinde klasik tedavi ile bariatrik cerrahi tedavisini karşılaştıran ilk ve en kapsamlı çalışma olan İsveç Obezite Çalışması (The Swedish Obese Subject Study/SOS) [21] sonuçlarına göre $(\mathrm{n}=4000)$; bariatrik cerrahi hastalarında ilk iki yıllık kilo kaybı 15-28 kg iken, klasik tedavi uygulanan hastalarda 0.5-8.9 kg'dır. Sekiz y1l sonunda bariatrik cerrahi hastalarının 16$20 \mathrm{~kg}$ kaybettiği, kontrol grubunun ise $0.7-12 \mathrm{~kg}$ kazandığı bildirilmiştir. İki y1l sonunda diyabet insidanslarının; bariatrik cerrahi hastalarında, kontrol grubuna göre 32 kat azaldığı, sekiz yıl sonunda ise bu oranın kontrol grubuna göre hala 5 kat az olduğu ifade edilmiştir. Benzer şekilde iki yıl sonunda bariatrik cerrahi grubunun hipertansiyon insidansının kontrol grubundan 2.6 kat az olduğu; sekiz yılın sonunda iki grubun insidans oranının neredeyse eşitlendiği saptanmıştır. Bu çalışmada bariatrik cerrahinin morbid obezlerde mortaliteyi azalttığı bildirilmiştir. Aynı karşılaştırmanın yapıldığı başka bir çalışmaya [22] göre bariatrik cerrahi geçiren hastalar kontrol grubuna göre ortalama $26 \mathrm{~kg}$ daha fazla ağırlık kaybetmektedirler. Buna ek olarak bariatrik cerrahi grubunun diyabet remisyon oranının daha fazla olduğu, yaşam kalitesinde diğer gruba göre artış sağlandığı ve ilaç kullanımında diğer gruba göre azalma gerçekleştiği bildirilmiştir. Obezite cerrahisinin güvenilirliğini konu alan bir derlemede; bariatrik cerrahinin $46 \mathrm{~kg}$ üzerinde vücut ağırlı̆̆ 1 kayb1 olduğu, diyabet remisyon oranının $\% 80$ ve diğer komorbiditelerin remisyon oranlarının da kayda değer olduğu bildirilmiştir [23].

Bariatrik cerrahinin mikrobiyota üzerine etkilerinin araştırıldığı bir derlemede; cerrahi sonrası bağırsaklarda kısa zincirli yağ asidi emilimine ve üretimine yardımcı olan Firmicutes bakterilerinde azalma olduğu ve birçok patojen bakterileri kapsayan Proteobacteria filumunda belirgin artış olduğu belirtilmiştir [24]. Bir başka çalışma Laparoskopik Sleeve Gastrektomi uygulanan 72 hastanın 2'sinde periferik nöropati geliştiğini ve bunun önlenmesi için postoperatif dönemde serum parametrelerinin yakından takip edilmesi gerektiğini vurgulamıştır [25].

\section{Obezitenin Cerrahi Tedavisi}

Bariatri kelimesi Yunanca'da kiloyu ifade eden 'bar' kelimesi ve tedaviyi ifade eden '-iatria' kelimelerinin birleşmesiyle oluşmuş ve dilimize geçmiştir [70]. Bariatrik cerrahi ilk olarak 1950'lerde Dr. Richard Varco tarafindan uygulanmıştır. Muhtemelen kilo kaybı amaçlanarak Jejunoileal Bypass (JIB) şeklinde uygulanan bu işlemin 1954 'te Kremen ve Linner tarafindan rapor olarak yayınlandığı belirtilmektedir $[26,27]$. Son 15-20 yılda laparoskopi ve endoskopi gibi tekniklerin geliştirilmesi ile ameliyatlar daha da çeşitlenmiştir [28, 29].

Bariatrik cerrahi yöntemleri; besin öğelerinin emilimini engelleyici malabsorbtif yöntemler ve besin alımını kısıtlayıcı restriktif yöntemler olmak üzere ikiye ayrılır. Ayrıca hem emilimi engelleyen hem de besin alımını kısıtlayan kombine yöntemler de vardır [18, 19, 30]. Restriktif yöntemler; İntragastrik Balon, Gastrik Pacing, Vertikal Band Gastroplasti (VBG), Laparoskopik Ayarlanabilir Gastrik Band (LAGB), Laparoskopik Sleeve Gastrektomi'dir (LSG) (Tüp Mide). Malabsorbtif 
yöntemler; Biliopankreatik Diversiyon (BPD), Jejunoileal Bypass (JIB) iken kombine yöntemler; Biliopankreatik Diversiyon-Duedonal Switch (BPD-DS), Roux en Y Gastrik Bypass (RYGB) ve Mini Gastrik Bypass'dır (MGB) [19, 30-33].

Bariatrik cerrahi için hasta seçiminde genel olarak National Institutes of Health'in (NIH) 1991 prensipleri [34] esas kabul edilmekte ve bu temel üzerinden güncellenmektedir.

Bariatrik cerrahi endikasyonları;

- $\mathrm{BKI}>40 \mathrm{~kg} / \mathrm{m}^{2}$ olmas 1 ya da $\mathrm{BKI}>35 \mathrm{~kg} / \mathrm{m}^{2}$ beraberinde; tip 2 diyabet, hipertansiyon, uyku apnesi, hiperlipidemi, reflü gibi komorbidite hastalıkların bulunması,

- Cerrahi tedavilerden önce uygulanan medikal tedavilerde başarısız olunması,

- Psikolojik durumun stabil olmas1,

- Aile ve çevre desteğinin yerinde olması,

- Alkol ve madde bağımlılığının olmaması,

- Hastanın yapılacak uygulama hakkında tam bilgi sahibi olmas1;

şeklinde sıralanabilir [33].

Bariatrik cerrahinin kontrendikasyonları ise;

- 18 yaşından küçük 65 yaşından büyük olmak,

- Anestezi veya ameliyatı engelleyen ciddi bir rahatsızlık varlığı,

- Tedavi edilemeyen endokrinolojik hastalık varlığı (Cushing sendromu, Hipotiroidizm vb.),

- Normal olmayan kan basinci durumu veya ciddi kardiyovasküler rahatsızlık varlığı,

- Kontrol dışı bulimia nevroza veya diğer yeme bozukluklarının varlığı,

- Gebelik,

- Hastaların prosedürü anlamasını engelleyecek derecede zihinsel yetersizlik,

- Hastalanın ameliyat sonrasında yaşam biçimini değiştirmedeki isteksizliği,

- Psikolojik dengesizlik,

- Hastanın ameliyatı 'sihirli değnek' gibi görmesi,

- Hastayı desteklemeyen ev halkı veya aile,

- Uyumsuz davranışlar;

şeklinde sıralanabilir [76, 77]. Bunların yanı sıra başka bir kaynakta obezite cerrahisinin 18 yaş altı ve 60 yaş üstü hastalarda, cerrah inisiyatifiyle donanımlı merkezlerde kontrollü şekilde gerçekleştirilebileceği bildirilmiştir [75].

\section{Restriktif Yöntemler}

\section{Intragastrik Balon}

İntragastrik balon ilk olarak 1980'lerde tanıtılmış, kullanılan kateterlerin keskin köşeler barındırması, zor yerleştirilmesi ve hastaları rahatsız etmesi dezavantajları nedeniyle başarısız olmuştur. Ardından gelişen teknoloji ile değişen materyallerle, geliştirilen laparoskopik ve endoskopik yerleştirme teknikleriyle zorluklar büyük oranda aşılmıştır [27]. Yöntem, erken doymayı indüklemek ve fazla besin alımını engellemek amaciyla radyoopak silikon elastik bir balonun doğrudan görüş altında endoskopik veya laparoskopik tekniklerle mideye yerleştirilmesi ve metilen mavisi ile renklendirilmiş izotonik $\mathrm{NaCl}$ ile şişirilmesi şeklinde uygulanır. Tam dolu mide hissinin oluşması, oreksijenik hormon salınımında azalma ve iştah baskılanması ile sonuçlanır. $\mathrm{Bu}$ durumun besin alımını azaltması beklenir. Görülen en büyük komplikasyon balonun yırtılmasına bağglı gastrointestinal obstrüksiyon ve ölümdür [35]. Diğer yöntemlere göre en az invaziv olan yöntemdir. Tek başına tercih edilen bir uygulama olmakla birlikte; genellikle diğer cerrahi yöntemlerin kullanılacağı hastalarda aşırı kilodan kaynaklanan komplikasyonların önüne geçmek için, yardımcı bir ön yöntem olarak tercih edilir. En fazla 6 aylık süre sonrasında balon yine endoskopi yardımı ile kontrollü bir şekilde çıkartılır $[14,36]$.

\section{Gastrik Pacing (Gastrik Stimülasyon)}

$\mathrm{Bu}$ yöntemde mideye ekseni boyunca (veya midenin bir kısmına) elektrot takımları implante edilir ve yapay elektriksel dalgalar gönderilir. Mideye gönderilen düzenli elektriksel dalgaların oluşturduğu kasılmalarla gastrik motor fonksiyon bozukluğu yaratılarak tokluk hissinin oluşturulması ve gida alımının azaltılması hedeflenir [37]. Gastrik pacing alanındaki ilk insan deneyleri 1990'larda başlamıştır. Cigaina (2002) gastrik pacing uygulamasındaki ilk insan deneylerini 1998 ve 2000 yıllarında 10 hastadan oluşan gruplara uygulamış, hastaların daha az yiyecekle doyduklarını bildirdiklerini, implante edilebilir gastrik pacing uygulamasının güvenli bir prosedür olduğunu, morbid obez bireylerde yeme alışkanlıklarını düzelttiğini bildirmiştir [38]. Onbir morbid obez hasta üzerinde yapılan bir başka çalışmada (2003) ise, hastaların serum leptin, somatostatin, glukagon benzeri peptin-1 (GLP-1) ve kolesistokinin seviyelerinin gastrik pacing uygulamasından önceki düzeylere göre anlamlı şekilde azaldığı bildirilmiştir. Yazarlar bu çalışmalarında GLP-1 seviyelerindeki azalmanın beklenmediğini, leptin seviyelerindeki azalmanın ise muhtemelen azalmış yağ doku kütlesinden kaynaklandığını belirtmişlerdir [39]. Gastrik pacing uygulamasının kısa dönemde kilo kaybı sağlanmak istenen hastalara önerildiği görülmektedir. LAGB veya VBG gibi diğer kısıtlayıcı yöntemlere kıyasla; reflüye yol açmaması bir avantajdır. Ayrıca diğer uygulamalara göre daha az komplikasyon ve risk barındırır. Fakat bu uygulamanın mekanizması hakkında çok az şey bilinmektedir. Bu uygulamanın uzun dönem sonuçlarını görebilmek, etki mekanizmasını anlayabilmek adına daha çok çalışmaya ihtiyaç vardır [39-42].

\section{Vertikal Band Gatroplasti (VBG)}

Bu yöntemin ilk sonuçları Mason tarafindan 1982 yılında yayınlanmıştır [71]. Bu cerrahi tedavide; 
gastrik fundustan başlanarak dikey bir şekilde stapler hattıyla, $30 \mathrm{ml}$ 'den daha az bir hacimde mide poşu oluşturulur. Yöntemde gastroözefageal bileşkenin $5 \mathrm{~cm}$ distalinden ve küçük kurvatür yanından mide duvarı ön ve arkadan delinir. Ardından stapler hattının sonundan yuvarlak açıklık oluşturularak süture edilir. Son olarak bandın çıkışına küçük kurvatürdeki geçişi çevreleyen 1.5 $\mathrm{cm}$ genişliğindeki poliprolen mesh (yama) konularak süture edilir [43]. Bu işlem; ağzın genişlemesini engellemek için yapılır [36]. Mason bu operasyonda, poş dilatasyonunu engellemek adına stapler hat başlangıcının gastrik fundusta olması gerektiğini vurgulamıştır. Bu uygulamada anastomoz kaçağı riski azdır ve herhangi bir bypass işlemi içermez. VBG günümüzde artık sı1k kullanılan bir yöntem değildir [36-44].

\section{Laparosopik Ayarlanabilir Gastrik Band (LAGB)}

Gastrik band ilk olarak 1980'lerde tanitılmaya başlanırken, 1986 yılında Kuzmak [72] deri altı bir porta bağlı sıvı giriş çıkışı ile ayarlanabilen silastik gastrik bandı tanıtmıştır ve 20. yüzyıl'ın sonlarına doğru laparoskopik ayarlanabilir gastrik band geliştirilmiştir [27]. Bu yöntemde silikon bir band gastroözefageal bileşkenin 2-3 cm altına yerleştirilerek 15-30 ml'lik bir mide poşu oluşturulmaktadır [31, 49]. Poşun alt kısmı ile altta kalan midenin üst kısmı sütüre edilir. Bandın devamı cilt altına yerleştirilir ve uygun görüldüğünde steril serum fizyolojik enjektesiyle bant sıkılıp gevşetilebilir [46]. Erken tokluk hissi yaratılarak besin alımı kısıtlanmaktadır [47]. LAGB; mide ve bağırsak rezeksiyonu gerektirmeyen, diğer uygulamalara kıyasla daha kolay uygulanan bir yöntemdir. Ayrıca malnütrisyon riski düşüktür. Tüm bunlara karşın bant kayması, bant açılması, bant perforasyonu veya penetrasyonu, gastroözefageal reflü, port enfeksiyonu, poş dilatasyonu, obstrüksiyon gibi komplikasyonlar taşımaktadır. Ayrıca ilk kilo kaybı diğer operasyonlara göre daha yavaştır [48, 49]. LAGB uygulamasının şematik bir gösterimi Şekil 1 'de verilmiştir.

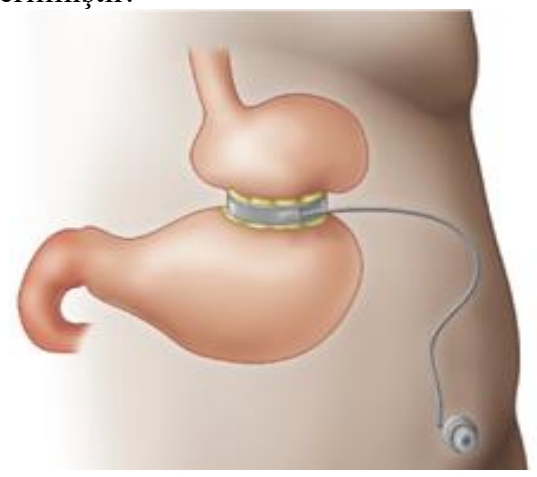

Şekil 1. LAGB Uygulamasının Şematik Bir Gösterimi [76].
LAGB uygulanan 94 hastanın sonuçlarının incelendiği bir çalışmada [45] 4 hastanın bandında (bir hastada 3. ayda, iki hastada 6. ayda ve bir hastada 12. ayda) açılma olduğu ve bandı açılan hastaların kilo kaybının durup kilo alımının tekrar başladığı bildirilmiştir.

Türkiye Endokrinoloji ve Metabolizma Derneği'nin (TEMD) 2018 Bariyatrik Cerrahi Kılavuzu'na göre LAGB uygulamasından sonra fazla kilo kayıp oranı $\% 43-45$, tip 2 diyabet remisyon oranı ise \%48-59 aralığında; aynı derneğin 2019 yılı kılavuzuna göre ise bu oranlar sirayla \%43-45 ve \%48-59 olarak verilmiştir [31, 62]. Banlı ve arkadaşlarının (2009) LAGB üzerine yaptıkları çalışmada $(n=100)$; hastaların 6. 12. 18. ayda fazla kilo kayıp oranının sirasıyla \%25.8, \%46.3, \%66 olduğu bildirilmiştir [50].

\section{Laparoskopik Sleeve Gastrektomi (LSG)}

Daha önceleri BPD-DS ameliyatının ilk aşaması olarak kullanılan fakat günümüzde tek başına kullanılmaya başlanmış bu yöntemde mide antrumundan başlanıp proksimal his açısında sona eren stapler hattı ile midenin yaklaşık \%80-85'i rezeke edilir $[25,47,51]$. Mide hacmi ortalama 100 ml'ye indirilir [46]. Geride gastrik fundus bırakmamak ve mide antrumunun geniş bırakılmaması gerekir. Midenin yeni görünümüne tüp şekli verildiği için tüp mide ameliyatı olarak da isimlendirilmektedir [36]. Ciddi kilo kayb1, pilor sfinkterin bütünlüğünün bozulmaması, ameliyat tekniğinin cerrah açısından kolay olması ve besin emilimini etkilememesi LSG'nin avantajlı yönleridir [25, 47]. Pilor sfinkteri zarar görmediği için dumping sendromu oluşmaz. Bunun yanı sıra oreksijenik bir hormon olan açlık hormonu olarak da bilinen ghrelin, gastrik fundustan bir miktar salgılandığ 1 için ameliyat sonrasında ghrelin düzeyleri, dolayısıyla iştah ve besin alımı azalmaktadır [48, 55]. Bužga ve arkadaşlarının [52] LSG uygulanan hastaların ameliyat sonrası serum leptin ve ghrelin düzeylerini araştırdıkları çalışmada $(n=37)$ postoperatif dönemde açlık kan glikozunun, leptin ve ghrelin düzeylerinin anlamlı şekilde azaldığı, buna karşın adiponektin düzeyinin ise arttığı bildirilmiştir. LAGB ve LSG sonrası plazma ghrelin seviyelerinin karşılaştırıldığ $(n=20)$ bir çalışmada ise [53] postoperatif 6 aylık süreçte LSG hastalarının plazma ghrelin düzeylerinin düşük ve stabil bulunduğu, LAGB hastalarının ise postoperatif 1. günde plazma ghrelin düzeylerinde preoperatif düzeylere göre değişiklik görülmezken 6 aylık süreçte arttığı saptanmıştır. Doğan ve arkadaşlarının [54] 36 hasta üzerinde gerçekleştirdiği bir çalışmada LSG'nin Helicobacter Pylori enfeksiyonunun tedavisinde efektif sonuçlar yarattığı bildirilmiştir. Ameliyat sonrası dönemde mide tüpünün genişlemesi karşılaşılan bir durum olduğundan yeniden LSG veya LSG sonrası gastrik bypass ya da BPD-DS 
gibi redo cerrahi yapılma riski ve anastomoz kaçağı riski vardır [33]. LSG sonrası hastaların nütrisyonel durumlarının dikkatli incelenmediği vakalarda makro ve mikro besin öğesi eksikliklerine bağlı olarak optik ve periferik nöropati gelişme olasıllğ 1 da vardır [25]. Brethauer ve arkadaşlarının [56] 24 çalışmayı irdeledikleri sistemik derlemede; LGS uygulanan hastalarda $(\mathrm{n}=1662)$ ortalama fazla kilo kayıp oranının $\% 55,4$ olduğu ve tip 2 diyabet remisyon oranının $(\mathrm{n}=754) \quad \% 70$ olduğu bildirilmiştir. TEMD 2019 Bariyatrik Cerrahi Kılavuzu'nda ise fazla kilo kayıp oranının \%55-70 arasında, tip 2 diyabet remisyon oranının ise \%6681 arasında olduğu bildirilmiştir. LSG uygulamasının şematik bir gösterimi Şekil 2'de verilmiştir.

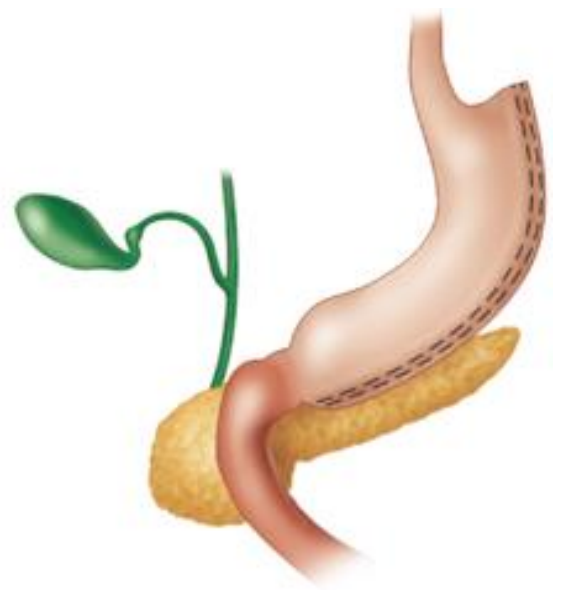

Şekil 2. LSG Uygulamasının Şematik Bir Gösterimi [76].

\section{Malabsorbtif Yöntemler}

\section{Jejunoileal Bypass (JIB)}

Bariatrik cerrahinin ve malabsorbtif türlerin atas1 olarak kabul edilen JIB ilk olarak 1950'lerin başında Dr. Richard Varco tarafindan bir hastaya uygulanmış, 1954'te Kremen ve Linner [74] tarafından rapor olarak yayınlanmıştır [26, 58]. Bu yöntemde tipik olarak jejunum $35 \mathrm{~cm}$ proksimalinden ayrilarak ileumun distalinden 10 $\mathrm{cm}$ uzağına bypass edilir. Jejunumun boşta kalan ucu ise uç noktadan sütüre edilir [28]. Özetle bağırsak boyunun kısaltıldığı bu uygulamada hiperfaji durdurulamasa da kilo verimi gerçekleşmektedir. Fakat karaciğer yetmezliği gibi ciddi komplikasyon riskleri barındırdığı anlaşıldığı ve yüksek mortalite oranlarıyla ilişkilendirildiği için 1970'lerde kullanımı bırakılmıştır [46, 59].

\section{Biliopankreatik Diversiyon (BPD)}

Bu uygulama ilk olarak 1950'lerde JIB şeklinde ortaya çıkmıştır. Ardından geliştirilmiş ve 1979 'da Scopinaro [73] BPD için dünya çapında uygulanan bir prosedür yayınlamıştır. Bu uygulamada midenin 2/3'lük kısmı distalden yatay şekilde rezeke edilerek geriye en fazla $500 \mathrm{ml}$ hacimli bir mide poşu bırakılır. Geriye bırakılan poş hacmi geniş olduğu için mide rezeksiyonu olsa da bu yöntem kısıtlayıcı yöntemler sınıfina girmemektedir [27]. İnce bağırsak, ileoçekal valvin $300 \mathrm{~cm}$ uzağından kesilerek geriye kalan mideye bağlanır. İnce bağırsağın bypass edilen bölümü ileoçekal valvin $50 \mathrm{~cm}$ uzağından birleştirilirken pilor ucu pankreas kanalı ile birleştirilir. $\mathrm{Bu}$ sayede biliopankreatik kanal ile beslenme kanalı (Roux kanalı) ileoçekal valvin $50 \mathrm{~cm}$ uzağında ortak bir kanal oluştururlar [46]. Bu sayede postoperatif süreçte özgür bir beslenme programı izlense bile kilo verimi gerçekleşmektedir. Fakat $50 \mathrm{~cm}$ 'lik kısıtlı bir emilim alanı olduğundan dolayı uzun dönemde makro ve mikro besin öğesi eksiklikleri sık görülmektedir. $\mathrm{Bu}$ durumun doğal sonucu olarak uzun dönemde kemik mineralizasyonu, proteinenerji malnütrisyonu, nörolojik bozukluklar, anemi gibi komplikasyon riskleri taşımaktadır. Bunun yanı sıra pilor sfinkteri korunmadığı için dumping sendromu ve marijinal ülser riski taşımaktadır [57]. Postoperatif dönemde mortalite riski yaklaşı \%1'dir [46]. Scopinaro ve arkadaşlarının (1998) BPD geçirmiş hastalar $(\mathrm{n}=2241)$ üzerinde yaptığı 21 yıllık çalışmada postoperatif fazla kilo kayıp oranının $\% 74 \pm 15$ olduğu bildirilmiş̧ir [57].

\section{Kombine Yöntemler}

\section{Biliopankreatik Diversiyon-Duedonal Switch (BPD-DS)}

Biliopankreatik Diversiyon-Duedonal Switch (BPD-DS) yalnızca Duedonal Switch (DS) olarak da adlandirılır [26]. Scopinaro'nun tanımladığ BPD uygulamasının zamanla değiştirilmesiyle 1990'da Marceau 'değiştirilmiş BPD' olarak adlandırılan uygulamanın ilkelerini tanımlamıştır. $\mathrm{Bu}$ tekniği BPD tekniğinden farklı k1lan noktalar horizontal gastrektomi yerine vertikal gastrektomi yapılması ve ortak kanal olarak adlandırılan bölgenin ileoçekal proksimalinden itibaren $50 \mathrm{~cm}$ değil 75-100 cm olmasıdır [33, 58]. BPD-DS uygulamasının şematik bir gösterimi Şekil 3'te verilmiştir.

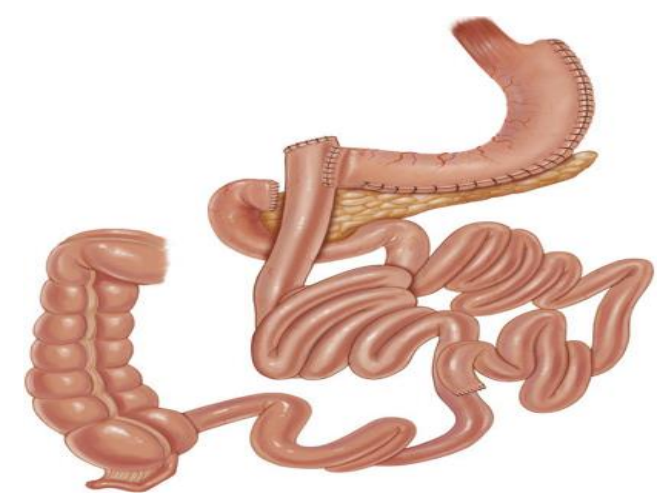

Şekil 3. BPD-DS Uygulamasının Şematik Bir Gösterimi [27]. 
Mide hacmi yaklaşık 100 ml’ye küçültüldüğü için

ve bağırsak bypass edildiği için hem restriktif hem de malabsorbtif bir yöntemdir. Hormonal denge ve metabolizma üzerinde de çeşitli etkileri mevcuttur. Emilim eksikliklerine neden olduğundan dolayı postoperatif dönemde nütrisyonel durumunun iyi bir şekilde gözlenmesi gerekir [27]. Uzun dönemde kilo kaybını ve komorbidite insidans oranını en iyi düşüren uygulama olmasına rağmen karmaşık bir ameliyat olması ve ameliyat komplikasyon risk oranının yüksek olması nedeniyle deneyimli merkezlerde gerçekleştirilmesi önerilir [55].

Hess ve Hess'in (1998) BPD-DS geçirmiş 440 morbid obez hasta üzerinde yaptıkları bir çalışmada postoperatif 24. ayda fazla kilo kayıp oranının \%80 olduğu; bu oranın postoperatif 8 . y1la kadar $\% 70$ civarında seyrettiği ve cerrahi tedavinin komorbidite hastalıklar üzerine olumlu etkilerinin olduğu bildirilmiştir [60].

\section{Mini Gastrik Bypass (MGB)}

İlk versiyonunu 1966 yilında Mason ve İto, Loop Gastrik Bypass adıyla uygulamışlardır [17]. Ancak safra gastriti ve özofajit ile biliyer yetersizliği nedeniyle kullanımı bırakılmıştır [23]. Ardından 1997 yılında MGB şeklini almış ve Rutledge 2001 yılında uygulamanın teknik ayrıntılarını ve ilk raporu yayınlamıştır [64]. Yöntemde küçük kurvatüre paralel bir stapler hattı his açısına kadar getirilerek küçük bir mide hacmi bırakılmaktadır. Gastrik tüpün distal ucu ince bağırsakla birleştirilir. Geride kalan mide bölümü süture edilerek devre dışı bırakılmış olur [64]. MGB uygulaması dünya genelinde çok az sıklıkta (\%1.5) kullanıldığ 1 bildirilmiştir [46].

\section{Roux en Y Gastrik Bypass (RYGB)}

Gastrik Bypass (GB) 1970'lerin sonunda tanınmaya başlanmış, RYGB yöntemi ise 2000'li yılların başında Loop Gastrik Bypass yönteminden evrilmiştir. Teknik olarak bypass edilmiş $30 \mathrm{ml}$ 'lik mide poşu'nun, 100-150 cm'lik roux kanalına bağlanması prensibine dayanır [61]. RYGB uygulamasının şematik bir gösterimi Şekil 4'te gösterilmiştir.

Midenin çok büyük bir kısmı ve bağırsağın bir bölümü bypass edildiği için etkinlik oranı yüksek bir yöntemdir. Fakat bu uygulamanın sonrasında mikro ve makro besin öğesi yetersizlikleri uzun dönemde görülebilecek komplikasyonlar olarak karşımıza çıkmaktadır [26, 46]. RYGB uygulamasında postoperatif fazla kilo kaybı ilk yıl $\% 60-70$ [51], sonraki 5 yıl içinde ise $\% 60$ civarında seyretmektedir $[46,62]$.

RYGB uygulanan 114 hastanın postoperatif dönem sonuçları üzerinde yapılan bir çalışmada; fazla kilo kayıp oranının postoperatif 3. ayda $\% 47.68$ ve postoperatif 12 . ayda $\% 85.04$ iken 24 . ayda $\% 83.5$ olduğu ve hipertansiyon, hiperlipidemi, uyku apnesi, tip 2 diyabet gibi hastalıkların anlamlı olarak düzeldiği bildirilmiştir [64].

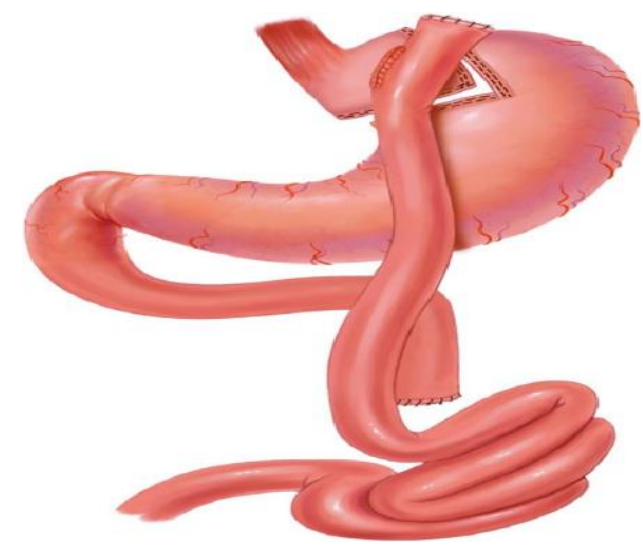

Şekil 4. RYGB Uygulamasının Şematik Bir Gösterimi [27].

Diğer yandan RYGB ile MGB uygulamalarının karşılaştırıldığ 1657 gastrik bypasslı hastayı kapsayan 10 yıllık bir çalışmada RYGB'nin operasyon süresinin ve komplikasyon riskini daha yüksek olduğu bunun yanında MGB'nin postoperatif 5 yılda fazla kilo kayıp oranının RYGB'den daha fazla olduğu bildirilmiştir [65]. Günümüzde bariatrik cerrahinin başarısı fazla kilo kayıp oranının \%50'den fazla olup olmamasıyla belirlenmektedir [62]. Postoperatif dönemde eğer hastaların fazla kilo kayıp oranı $\% 40$ ve altındaysa uygulama başarısız, \%40-60 aralığında ise orta düzeyde başarılı ve $\% 60$ ve üzerinde ise iyi düzeyde başarılı olarak kabul görür [19, 66, 67]. TEMD 2019 Obezite Tanı ve Tedavi Kılavuzu'na göre en çok kullanılan ve artık standart olarak kabul edilmiş yöntemler; LSG, LAGB, BPD-DS ve RYGB'dir ve bariatrik cerrahiye bağlı mortalite oranı yaklaşık \%1'dir [55]. Fakat LAGB kullanımının son zamanlarda belirgin şekilde azaldığı bildirilmiştir [68]. Postoperatif dönemde yapilan beslenme ve metabolik kontrollerin periyotları uygulamadan uygulamaya farklılık göstermesine rağmen ilk 1-3 y1l içerisinde intestinal adaptasyonun sağlanması beklenir [69]. Bazı standart uygulamaların kontrol süreleri Tablo 2'de yer almaktadir.

\section{SONUÇ}

Bariatrik cerrahi uygulamalar1; morbid obezite tedavisinde diyet ve farmakolojik tedaviye göre başarı şansı oldukça yüksek olan; perioperatif süreçte cerrah, diyetisyen, hemşire, fizyoterapist, psikolog gibi birçok uzman tarafından gerçekleştirilen multidisipliner bir ekip çalışmasıdır. Geçmişi 1950’lere dayanan ve ilk olarak Jejunoileal Bypass (JIB) olarak uygulanan bariatrik cerrahi uygulamaları günümüzde gelişen teknoloji ile birlikte güncellenmekte, değiştirilmekte ve çeşitlendirilmektedir. Örneğin 
JIB uygulaması zamanla geliştirilerek Biliopankreatik Diversiyon (BPD) şeklini almış, o da zamanla bazı teknik değişiklikler yapılarak Biliopankreatik Diversiyon-Duedonal Switch (BPD-DS) şeklinde uygulanmaya başlanmıştır. BPD-DS günümüzde sık tercih edilen başarı oranı yüksek bir uygulamadır. Fakat JIB uygulaması yüksek mortalite riski barındırdığı anlaşıldığından dolayı günümüzde artık tercih edilmemektedir. Günümüzde kullanımı tercih edilmeyen bir diğer uygulama da Vertikal Band Gatroplasti'dir (VBG). Diğer uygulamalara göre ortaya çıkışı çok da eskiye dayanmayan Gastrik Pacing uygulaması kisa dönemde kilo kaybı sağlanmak istenilen hastalarda uygulanmaktadır fakat uzun dönem sonuçlarını görebilmek adına daha çok çalı̧̧maya ihtiyaç duymaktadır. İntragastrik balon uygulaması gelişen teknolojiyle uygulama kolaylığı ve popülerlik

kazanmış günümüzde kısa dönemde kilo kaybı sağlanmak istenen hastalara uygulanmaktadır. Diğer pek çok yönteme kıyasla daha az invaziv bir yöntem sayılabilecek Laparosopik Ayarlanabilir Gastrik Band (LAGB) uygulamas1 günümüzde kullanım kolaylığından dolayı sik tercih edilen uygulamalar arasındadır. Roux en Y Gastrik Bypass (RYGB) teknik olarak Loop Gastrik Bypass uygulamasından evrilmiş olup günümüzde başarı oranı ve kullanım sıklığı fazla olan uygulamalar arasındadır. Laparoskopik Sleeve Gastrektomi (LSG) daha önce BPD-DS uygulamasının ilk aşaması olarak uygulansa da günümüzde tek başına uygulanmakta olan başarı oranı yüksek bir uygulamadır. Mini Gastrik Bypass ise dünya genelinde çok az sıklıkta kullanılan bir yöntemdir. Her biri birçok avantaj ve dezavantaj barındıran ve bazıları artık kullanılmayan bu uygulamalar arasından hastaya uygun olanı pek çok faktör göz önünde bulundurularak seçilmektedir. Tüm bu uygulamalara gün geçtikçe revize edilmekte kullanımı bırakılanların yerine yenileri eklenmekte ve daha az risk barındıran hasta ve cerrah açısından kolay olan uygulamalar geliştirilmeye çalışılmaktadır. Sürecin başarılı bir şekilde gerçekleşmesi için hastaya uygun yöntemin tercih edilmesi, ekip tarafindan süreç boyunca hastanın kapsamlı bir şekilde takip edilmesi, cerrahi tedavi sonras1 eğitimlerinin yapılması, diyetisyenler tarafindan hastaların beslenme programlarının, hasta gereksinimleri gözetilerek düzenlenmesi, gerektiğinde güncellenmesi ve hastanın çok iyi bir şekilde izlenmesi son derece önemlidir.

Tablo 2. Bazı Standart Uygulamalarının Postoperatif Dönem Kontrol Periyotları [69].

\begin{tabular}{|c|c|c|c|c|c|}
\hline İŞLEM & Komorbidite & İlk 6 ay" & İkinci 6 ay & İkinci yıl & 2 yil ve sonrası \\
\hline \multirow[t]{2}{*}{ LAGB } & Yok & Her ay $1 \mathrm{kez}$ & $1 \mathrm{kez}$ & Yillik & Y1ll1k \\
\hline & Var & Her ay $1 \mathrm{kez}$ & $2 \mathrm{kez}$ & Her 6 ayda $1 \mathrm{kez}$ & Yillık \\
\hline \multirow[t]{2}{*}{ RYGB } & Yok & Her $2-3$ ayda $1 \mathrm{kez}$ & $1 \mathrm{kez}$ & Her 6 ayda $1 \mathrm{kez}$ & Yillık \\
\hline & Var & Her $1-2$ ayda $1 \mathrm{kez}$ & Her 3-6 ayda $1 \mathrm{kez}$ & Her 6 ayda $1 \mathrm{kez}$ & Yillik \\
\hline \multirow[t]{2}{*}{ BPD-DS } & Yok & Her 2-3 ayda $1 \mathrm{kez}$ & $2 \mathrm{kez}$ & Her 3-6 ayda $1 \mathrm{kez}$ & Y1llik \\
\hline & Var & Her $1-2$ ayda $1 \mathrm{kez}$ & Her 6-12 ayda $1 \mathrm{kez}$ & Her 6-12 ayda $1 \mathrm{kez}$ & Her 6-12 ayda $1 \mathrm{kez}$ \\
\hline
\end{tabular}

* İlk kontrol postoperatif ilk ayda yapılmak üzere.

\section{KAYNAKÇA}

[1] https://www.who.int/topics/obesity/en/,

(Erişim Tarihi: 27.09.2019).

[2] http://www.assessmentpsychology.com/icbmi.htm, (Erişim Tarihi: 27.09.2019)

[3] Baş B. Obezite cerrahisi öncesi ve sonras1 hastaların yaşam kalitesi, Yüksek Lisans Tezi, Maltepe Üniversitesi, 2018.

[4] Baysal A., Aksoy M., Besler T., Bozkurt N., Keçecioğlu S., Mercanlıgil S.M., vd. Diyet El Kitabı, Ankara, Hatiboğlu Yayınevi, p.654, 2013.

[5] İlhan B.Ö. Obezite cerrahisinin benlik saygısı ve yaşam kalitesine etkisi, Yüksek Lisans Tezi, Maltepe Üniversitesi, 2018.

[6] https://apps.who.int/iris/bitstream/handle/10665/44 583/9789241501491_eng.pdf;jsessionid=0C61B60 8AE0B761 A86E8DCB0DDE892E4? sequence=1, (Erişim Tarihi: 27.09.2019).

[7] http://tuik.gov.tr/PreHaberBultenleri.do?id=24573, (Erişim Tarihi: 27.09.2019).

[8] https://www.who.int/gho/en/, (Erişim Tarihi: 27.09.2019).

[9] Baltacı G. Obezite ve Egzersiz, Ankara, Sağlık Bakanlığı Yayınları, p.20, 2008.
[10] Gürel S.F., İnan G. Çocukluk çağı obezitesi tanı yöntemleri, prevalansı ve etyolojisi, Adnan Menderes Üniversitesi Tıp Fakültesi Dergisi, 2(3), 39-46, 2001.

[11] Stunkard A.J., Sørensen T.I.A., Hanis C., Teasdale T.W., Chakraborty R., Schull W.J., vd. An adoption study of human obesity, New England Journal of Medicine, 314(4), 193-8, 1986.

[12] Alphan M.E.T., Baş M., Baysal A., Kutluay T.M., Kiziltan G., Pekcan G. Hastalıklarda Beslenme Tedavisi, Ankara, Hatiboğlu Yayınevi, p.1044, 2014.

[13] Kurniati N. Obesity and central obesity, Medical Journal of Indonesia, 27(2), 69-70, 2018.

[14] Tam A., Çakır B. Birinci basamakta obeziteye yaklaşım, Ankara Medical Journal, 12(1), 37-41, 2012.

[15] Branca F., Nikogosian H., Lobstein T. The Challenge of Obesity in he WHO European Region and the Strategies for Response: Summary, World Health Organization, Danimarka, p.56, 2007.

[16] Serter R. Obezite Atlas1, Ankara, Karakter Color Basımevi. p.136, 2004.

[17] Açıkgöz A.Ö. Morbid obezite cerrahisi geçiren hastalarda zor havayolu insidansı ve eşlik eden hastalıklar, Uzmanlık Tezi, Hacettepe Üniversitesi, 2014. 
[18] Dizlek D., Çatal E. Morbid obezitede bariatrik cerrahi sonrası hasta sonuçları, Düzce Üniversitesi Bilim ve Teknoloji Dergisi, 6(2), 501-12, 2018.

[19] Korkmaz M.F. Bariatrik cerrahinin morbid obez bireylerde total antioksidan kapasite üzerine etkisi, Uzmanlık Tezi, Fırat Üniversitesi, 2018.

[20] Baltacı D., Ünalacak M., Kara İ.H., Sarıüzel Y.C. Birinci basamakta obezite tedavisi, Turkiye Klinikleri Family Medicine-Special Topics, 6(3), 96-102, 2015.

[21] Torgerson J.S., Sjöström L. The swedish obese subjects (SOS) study rationale and results, International Journal of Obesity, 25(1), 2-4, 2001.

[22] Gloy V.L., Briel M., Bhatt D.L., Kashyap S.R., Schauer P.R.,Mingrone G., Bariatric surgery versus non-surgical treatment for obesity: a systematic review and meta-analysis of randomised controlled trials, British Medical Journal, 347 1-16, 2013.

[23] Pories W.J. Bariatric surgery: risks and rewards, The Journal of Clinical Endocrinology and Metabolism, 93(11), 89-96, 2008.

[24] Uzdil Z., Saka M. Bariatrik cerrahi uygulamalarının mikrobiyota üzerine etkilerinin değerlendirilmesi, Gazi Sağlık Bilimleri Dergisi, 3(1), 38-44, 2018.

[25] Erol V., Öztürkeri Ö.A., Yılmaz T.H., Emre S., Gülay H. Management of peripheric neuropathy following laparoscopic sleeve gastrectomy, Cerrahi Sanatlar Dergisi, 9(1), 35-9, 2016.

[26] Deveci E. Obezite cerrahisi adayı olan ve olmayan obez bireylerde yeme özellikleri, beden bölgesinden hoşnutsuzluk, tedavi motivasyonu ve psikopatolojinin değerlendirilmesi, Yüksek Lisans Tezi, İstanbul Üniversitesi, 2013.

[27] Buchwald H. Buchwald's Atlas of Metabolic and Bariatric Surgical Techniques and Procedures, Filedelfiya, Elsevier, p.370, 2011.

[28] Buchwald H., Buchwald J.N. Evolution of operative procedures for the management of morbid obesity 1950-2000, Obesity Surgery, 12(5), 705-17, 2002.

[29] O'Brien P. Bariatric surgery: mechanisms, indications and outcomes, Journal of Gastroenterology and Hepatology, 25(8), 1358-65, 2010.

[30] Aydın E., Bulut H. Bariatrik cerrahide hemşirelik bakımı. TAF Preventive Medicine Bulletin, 13(1), 77-82, 2014.

[31] Bariyatrik Cerrahi Kılavuzu, Türkiye Endokrinoloji ve Metabolizma Derneği, Ankara, Miki Matbaacılik, p.95, 2018

[32] Işık D. Sleeve gastrektomi uygulanacak hastalara verilen sistematik eğitimin ameliyat sonrası 3 aylık dönemdeki antropometrik değerlerine ve besin tüketimlerine etkisi, Yüksek Lisans Tezi, Adnan Menderes Üniversitesi, 2019.

[33] Sağlam F., Güven H. Obezitenin cerrahi tedavisi, Okmeydanı Tip Dergisi, 30(1), 60-5, 2014.

[34] NIH. Gastrointestinal surgery for severe obesity, Obesity Surgery, 1 257-65, 1991.

[35] Bor S., Turan İ., Özütemiz Ö. Morbid obezite tedavisinde intragastrik balon uygulaması sırasında meydana gelen balon rüptürü vakası, Akademik Gastroenteroloji Dergisi, 6(2), 94-6, 2007.

[36] Kılıç O. Slevee gastrektomili hastaların uzun dönem klinik sonuçları, Uzmanlık Tezi, Pamukkale Üniversitesi, 2016.
[37] Chiu J.D., Soffer E. Gastric electrical stimulation for obesity, Current Gastroenterology Reports, 17(4), 1-6, 2015.

[38] Cigaina V. Gastric pacing as therapy for morbid obesity: preliminary results, Obesity Surgery, 12(1), 12-6, 2002.

[39] Cigaina V., Hirschberg A.L. Gastric pacing for morbid obesity: plasma levels of gastrointestinal peptides and leptin, Obesity Research, 11(12), 1456-62, 2003.

[40] Miller K. Laparoscopic Gastric Pacing, Obesity, Bariatric and Metabolic Surgery, S. Agrawal (ed.), Switzerland, Springer, p.736, 2015.

[41] Hipertansiyon, Obezite ve Lipid Metabolizmas1 Hekim İçin Tanı ve Tedavi Rehberi. Türkiye Endokrinoloji ve Metabolizma Derneği, Ankara, Miki Matbaacilık, p.112, 2009.

[42] Favretti F., Luca M.D., Segato G., Busetto L., Ceoloni A., Magon A., vd. Treatment of morbid obesity with the Transcend Implantable gastric stimulator: a prospective survey, Obesity surgery, 14(5), 666-670, 2004.

[43] Fobi M.A.L., Fleming A.W. Vertical banded gastroplasty vs gastric bypass in the treatment of obesity, Journal of the National Medical Association, 78(11), 1091-1098, 1986.

[44] Güler Y., Sakarya A. Morbid obezite ve cerrahi tedavisi, İzmir Tepecik Eğitim ve Araştırma Hastanesi Dergisi, 15(3), 139-53, 2005.

[45] Sakçak İ., Avşar F.M., Hamamcı E.O., Bostanoğlu S., Sonışık M., Bostanoğlu A., Laparoskopik ayarlanabilir stomalı mide band1 uygulamalarında nadir bir komplikasyon: bant açılması (atnalı görünümü), Turkish Journal of Surgery, 25(4), 161164, 2009.

[46] Türkiye'de Obezite Tedavisinde Obezite Cerrahisinin Yeri, Sağlık Teknolojisi Değerlendirme Daire Başkanlığı (STDD), Ankara, p.153, 2014.

[47] Güçlü A. Bariatrik cerrahi ve perioperatif hemşirelik bakımı, Sürekli Tıp Eğitimi Dergisi, 27(3), 209-11, 2018.

[48] Suraweera D., Saab E.G., Choi G., Saab S. Bariatric surgery and liver transplantation, Gastroenterology and Hepatology, 13(3), 170-175, 2017.

[49] Gilbert E.W., Wolfe B.M. Bariatric surgery for the management of obesity: state of the field, Plastic and Reconstructive Surgery, 130(4), 948-954, 2012.

[50] Banlı O., Altun H., Karakoyun R., Özdoğan H., Kahveci K., Çakmak B. Obesite tedavisinde laparoskopik gastrik band yerleştirilmesi sonuçları: ilk 100 olgu, Turkish Journal of Surgery, 25(1), 1114, 2009

[51] Ruban A., Stoenchev K., Ashrafian H., Teare J. Current treatments for obesity, Clinical Medicine, 19(3), 205-212, 2019.

[52] Bužga M., Zavadilová V., Holéczy P., Švagera Z., Švorc P., Foltys A., Dietary intake and ghrelin and leptin changes after sleeve gastrectomy, Videosurgery and Other Miniinvasive Techniques, 9(4), 554-561, 2014.

[53] Langer F.B., Hoda M.A.R., Bohdjalian A., Felberbauer F.X., Zacherl J., Wenzl E., vd. Sleeve gastrectomy and gastric banding: effects on plasma ghrelin levels, Obesity Surgery, 15(7), 1024-1029, 2005 . 
[54] Doğan U., Ensari C.Ö., Çöpelci Y., Öner O.Z., Oruç M.T., Bülbüller N. Laparoskopik sleeve gastrektominin helicobacter pylori enfeksiyonuna etkisi, Ankara Üniversitesi Tıp Fakültesi Mecmuas1, 71(2), 166-169, 2018.

[55] Obezite Tanı ve Tedavi Kılavuzu, Türkiye Endokrinoloji ve Metabolizma Derneği, Ankara, Miki Matbaacilık, p.112, 2019.

[56] Brethauer S.A., Hammel J.P., Schauer P.R. Systematic review of sleeve gastrectomy as staging and primary bariatric procedure, Surgery for Obesity and Related Diseases, 5(4), 469-475, 2009.

[57] Scopinaro N., Adami G.F., Marinari G.M., Gianetta E., Traverso E., Friedman D., vd. Biliopancreatic diversion, World Journal of Surgery, 22(9), 936946, 1998.

[58] Agrawal S. Obesity, Bariatric and Metabolic Surgery: A Practical Guide, Switzerland, Springer, 2015, p.736.

[59] Singh D., Laya A.S., Clarkston WK., Allen M.J. Jejunoileal bypass: a surgery of the past and a review of its complications, World Journal of Gastroenterology, 15(18), 2277-2279, 2009.

[60] Hess D.S., Hess D.W. Biliopancreatic diversion with a duodenal switch, Obesity Surgery, 8(3), 267282, 1998.

[61] Elder K.A., Wolfe B.M. Bariatric surgery: a review of procedures and outcomes, Gastroenterology, 132(6), 2253-2271, 2007.

[62] Bariyatrik Cerrahi Kılavuzu. Türkiye Endokrinoloji ve Metabolizma Derneği, Ankara, Miki Matbaacilık, p.95, 2019.

[63] Görgün M., Tepel M.A., Sezer T.Ö., Bademkıran E. Laparoskopik roux-en-y gastrik bypass (lrygbp): teknik, sonuçlar ve 114 hastalı deneyim, Endoskopik Laparoskopik ve Minimal İnvaziv Cerrahi Dergisi, 17(1), 24-37, 2010.

[64] Rutledge R. The mini-gastric bypass: experience with the first 1,274 cases. Obesity Surgery. 11(3), 276-280, 2001.

[65] Lee W.J., Ser K.H., Lee Y.C., Tsou J.J., Chen S.C., Chen J.C. Laparoscopic roux-en-y vs. mini-gastric bypass for the treatment of morbid obesity: a 10year experience. Obesity Surgery, 22(12), 18271834, 2012.

[66] Yüksel A. Bariatrik cerrahi operasyonu geçiren morbid obez bir hastanın 3 yll sonraki beslenme durumu: olgu sunumu, İzmir Kâtip Çelebi Üniversitesi Sağlık Bilimleri Fakültesi Dergisi, 1(1), 39-45, 2016.

[67] Türkçapar A. Bariatrik cerrahide reoperasyon, Endoskopik Laparoskopik ve Minimal İnvaziv Cerrahi Dergisi, 17(1), 46-55, 2010.

[68] Angrisani L., Santonicola A., Iovino P., Formisano G., Buchwald H., Scopinaro N. Bariatric surgery worldwide 2013, Obesity Surgery, 25(10), 18221832, 2015.

[69] Mechanick J., Kushner R., Sugerman H., Campoy J.G., Clavell M.C., Guven S., vd. American association of clinical endocrinologists, the obesity society, and american society for metabolic and bariatric surgery medical guidelines for clinical practice for the perioperative nutritional, metabolic, and nonsurgical support of the bariatric surgery patient, Endocrine Practice, 14, 1-83, 2008.
[70] Berdanier C.D., Dwyer J.T., Feldman E.B. Handbook of Nutrition and Food. Boca Raton, London, New York: CRC press, p.1247, 2007.

[71] Mason E.E. Vertical banded gastroplasty for obesity. Archives of surgery, 117(5), 701-706, 1982.

[72] Kuzmak L.I. Silicone gastric banding: a simple and effective operation for morbid obesity. Contemporary Surgery, 28, 13-18, 1986.

[73] Scopinaro N., Gianetta E., Civalleri D., Bonalumi U., Bachi V. Biliopancreatic bypass for obesity: II. Initial experience in man. British Journal of Surgery, 66, 618-620, 1979.

[74] Kremen A.J., Linner J.H., Nelson C.H. An experimental evaluation of the nutritional importance of proximal and distal small intestine. Annals of Surgery. 140(3), 439, 1954.

[75] SAGES Guidelines Committee. SAGES guideline for clinical application of laparoscopic bariatric surgery. Surgical Endoscopy, 22(10), 2281-2300, 2008.

[76] Schırmer B., Schauer P.R. The Surgical Management of Obesity. Schwartz's Principles of Surgery Ninth Edition. USA, McGraw-Hill Companies, p.952-3, 2010.

[77] Sabuncu T., Kiyıc1 S., Eren M.A. Sancak S., Sönmez A., Güldiken S. et al. Summary of bariatric surgery guideline of the society of endocrinology and metabolism of turkey. Turkish Journal of Endocrinology and Metabolism, 21, 140-147, 2017. 